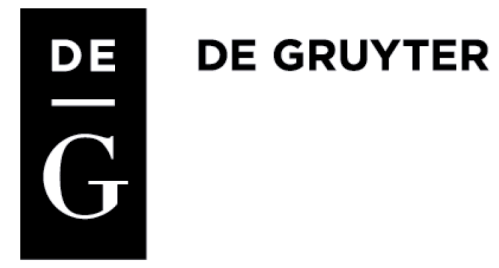

Paweł Grata (University of Rzeszów)

\title{
AT THE ORIGINS OF WELFARE STATE? SOCIAL EXPENSES IN THE BUDGETARY POLICY IN THE SECOND POLISH REPUBLIC
}

In the period of the Second Polish Republic, social policy became an important field of activity for public authorities. It was distinguished by a high level of awareness of the prevalent social problems, progressive legislation, and advanced management. The only missing element was sufficient financing. In the budgetary policy of the Second Polish Republic, social expenses were of minor importance. For the most part of the period, they amounted to approximately $3 \%$ of all expenses. The Ministry of Social Care was underfunded, which was evident in nearly every aspect of its activity. Hence, if one wonders if the origins of the Polish welfare state can be traced back to the Second Polish Republic, the answer must be "no". Although extra funds (spent on tackling unemployment, pensions, or disability benefits) were found outside of the ministerial budget, the arguments presented in this article only confirm the hypothesis presented above.

Key words: social policy, state budget, welfare state, social expenses, Ministry of Social Care

doi:10.1515/sho-2017-0002

\section{INTRODUCTION}

The concept of the welfare state emerged in Western Europe and AngloSaxon countries after the Second World War as a result of a long development of the social activity of the state. Its evolution was accelerated by the Great Depression and the Second World War trauma. These events made social policy extremely important in the functioning of public authorities, and the expansion of social functions of the state was followed by an abrupt increase in state budget expenditure for broadly understood social purposes. 
As the welfare state granted citizens access to a wide and increasing range of social protection mechanisms, benefits and services, it also became more expensive to finance. In the final decades of the $20^{\text {th }}$ century, expenses related to fulfilling welfare state obligations in some countries even exceeded $30 \%$ of their GDP, clearly becoming the most significant figure in the state budget and consuming over $50 \%$ of means redistributed annually by the state (despite systemic differences, similar trends were observed in European socialist states). Increase in expenditure for social purposes was also observed in Poland after the Second World War. In the late $20^{\text {th }}$ century, its share in the budget was comparable to that seen in the most developed western welfare states. This resulted from the expansion of social services, which took place in the ideologically socialist state, as well as the principles adopted in this respect in the period of systemic transformation, which aimed at achieving "a social market economy", as it was referred to in the 1997 constitution (Księżopolski M. 1999: 43-45; Nadolska A. 2003: 111).

Though the welfare state developed mainly after the WWII, it must be noted that its origins are to be found earlier, in processes that had shaped the principles of social policy understood as the involvement of the state and other entities in solving social issues. For the most part, the foundations of these principles had been created before the WWII, and their range had been quite broad even at that time. Therefore, it is worth investigating the role of the public authorities' social activity in the budgetary policy of the period preceding the emergence of the welfare state, when social policy was becoming a mature form of the state's interaction with the society, especially as a result of the Depression. At the same time, it was still very much restricted by the traditional perception of the role of this institution in the economic life and, consequently, by the limited financial capabilities imposed by the classic rules of fiscal policy. The Second Polish Republic can be an interesting subject of such analysis, as it demonstrates both the development of social policy in the years 1918-1939, and the existing economic, ideological, political and financial barriers to its implementation. 


\section{THE SCOPE OF THE STATE'S SOCIAL FINANCIAL LIABILITIES IN THE YEARS 1918-1939 (THE SECOND POLISH REPUBLIC)}

The development of the state's social activity in the years 1918-1939 was quite progressive, and the social policy of the public authorities could be considered advanced. In this period, the policy included not only traditional issues related to the "labor problem", i.e. labor legislation and social insurance, but also social welfare (which was supposed to complement the work of insurance companies), health care, and employment policy (increasingly important as the threats in the labor market escalated).

Poland, undergoing reconstruction after the period of partitions, was no different. From the very beginning of its independence, the young state had to face the challenge of creating a social policy system that would incorporate diverse solutions functioning in each of the three partitions. On the one hand, this diversity was a great burden, but on the other, opened up an opportunity to create Poland's own system based on the most advanced European models. This was the direction that the state authorities took in the first months of independence, and the labor legislation introduced in the years 1918-1922 faithfully followed the canon in this respect [Polityka... (Policy...), 1935: 78-96].

Regarding other aspects of social policy, the establishment of Poland's own system was much harder. No one doubted the importance of social insurance, and sickness insurance was introduced as early as 1919 . However, the process of creating the appropriate legal and organizational frameworks took more than ten years and was not concluded until 1934, when the regulations providing workers in former Austrian and Russian partition territories with old age and disability insurance entered into force (until that moment such insurance only existed in the former Prussian partition). Policy in the area of employment and unemployment was also partially connected to insurance. The Act of 1924 provided financial benefits to the insured who became unemployed. In the 1930s, a separate budgetary entity, the Labor Fund, was established to undertake actions aiming at providing financial support and assistance in finding employment [Fundusz... (The Labor Fund...), 1934: 11; Jarosz-Nojszewska A. 2013: 29_ 38; Muszalski W. 2004: 52-55].

However, throughout the whole inter-war period, it was not possible to create firm and solid foundations for the functioning of social welfare 
and health care system. Neither the Act on Social Care of August 1923, nor the General Sanitary Act of 1919 managed to achieve that, and the fundamental regulations of the Act on Public Health Care of June 1939 were to enter into force only in the spring of 1940. Importantly, though, the state transferred most of its responsibilities regarding both of these fields of social policy onto local governments, and left central authorities to deal with only selected aspects of its functioning and to provide supervision [Grata P. 2016: 129-142; idem 2014b: 69-77].

This rather complicated structure of the social policy system meant that the level of the state's organizational and financial engagement was uneven. In the case of labor legislation, state institutions (including the most prominent one - the Labor Inspectorate) were responsible for the enforcement of the existing regulations. In terms of social insurance, the role of the state was limited to supervision and subsidizing some benefits under the existing insurance regulations. The state also subsidized unemployment insurance contributions, supported selected aspects of care provision activities, organized sanitary supervision, subsidized fight against infectious and social diseases, financed psychiatric hospitals, and co-financed the creation of a network of health centers intended to become the basis of commonly available public health care.

This set of financial liabilities associated with social policy was reflected by the share of social expenses in the budgetary policy of the Second Polish Republic. What remains important, though, is that for the most part of the inter-war period, these expenses were distributed among more than just one ministry. Until 1923, the state's social activity was the responsibility of the Ministry of Labor and Social Care and the Ministry of Public Health. Later, health care-related issues became part of the remit of the Ministry of Home Affairs. The management of the basic aspects of social policy was consolidated as late as 1932, when health care provision was included in the tasks of the Ministry of Labor and Social Care, which from then on was referred to as the Ministry of Social Care. Only from that moment on was social policy consistently managed and financed. At that point, its place in fiscal expenditure and the expense structure was strictly related to the work of the Ministry of Social Care [Grata P. 2013: 43-50]. 


\section{EXPENDITURE ON SOCIAL PURPOSES IN THE STATE'S BUDGET}

The fiscal policy of the Second Polish Republic was fundamentally based on the rule of budgetary balance, unquestionable according to the doctrine of the time. Even though the balance was not always possible to achieve, the principle was irrefutable, which significantly affected many expenditure items, also those related to social welfare.

When monetary relations were stable, the structure of budgetary expenditure was stable as well and accurately reflected the state's priorities. Most resources were devoted to defense, which regularly comprised around $1 / 3$ of all fiscal expenses. Around $1 / 6$ was allocated to the Ministry of Denominations and Public Enlightenment. In total, these two main fields of state activity regularly consumed half of the budget. Less than $10 \%$ of resources was spent on internal security, and a similar amount was spent on the repayment and management of public debt. A further $20 \%$ was consumed by the Ministry of State Treasury and the state pensions and disability benefits subsidized by this institution. What is also important, this structure of distribution was very stable, and significant exceptions were only made in the early 1920s, which were a period of intense inflation and troubles in the fiscal economy of the state [Grata P. 2014a: 401-405].

The position of social issues in the budget was quite marginal in the Second Polish Republic. Neither the administrative structures responsible for the particular components of social policy nor the condition of the budget had any influence on changing this situation. Whether the budget generated a significant surplus (e.g. in the mid-1920s) or suffered from extreme deficits (in the period of Depression), the importance of social care was equally small. The resources allocated for the needs of the ministries established to implement the goals of the social policy were assumed to be small and comprised from two to seven percent of the state budget at most - this was the standard in the whole period except for the first months of independence and the budgetary chaos of the year 1923 marked by hyperinflation.

What is also significant, social care comprised the highest share of the budget in the beginning of the Depression, when increased needs to support the unemployed were reflected by the increase in expenses from the state budget - which was still in quite a good condition and enjoyed the surplus from the previous years. In this period, the state subsidized the 
organization of public works and the so-called special assistance to those unemployed who were not entitled to unemployment benefits. In the years 1930-1931, nearly 50 million PLN was spent from the state budget on this sort of assistance - almost as much as the size of the whole budget of the Ministry of Labor and Social Care in the year 1928/1929 (in the year 1931, alone 110 million PLN was spent in total from the Ministry's budget to support the unemployed). The worsening condition of the budget led to the discontinuation of financial benefits. In the autumn of 1931, financial benefits were replaced by in-kind support (mainly food) [BornsteinŁychowska M. 1931: 359-360; Polityka... (Social policy...), 1935: 165-166].

Budgetary expenditure for social purposes returned to its naturally low level in the budgetary year 1934/1935. Even though it was subjected to the Minister of Social Care, the Labor Fund had its own separate sources of income. When the Fund was established, it took over tasks related to assisting the unemployed and financing public works. This meant that the level of social expenses stabilized in the mid-1930s. In the conditions of a formally balanced fiscal economy, less than 3\% of the budget was typically spent for the purposes of the Ministry of Social Care. Experts in the field regularly complained about the situation and pointed out that this did not allow the state to perform even its basic tasks in this respect [Dz.U. (Journal of Laws), 1933: 22/163; 1934, 94/849; Fundusz..., 1934: 11-20].

The resources allocated for social issues were so low that even the author of the parliamentary commission report on the ministerial budget for the year 1937/1938, Leopold Tomaszkiewicz wrote:

if someone wanted to assess the reality of Poland based on the figures in the budget of the Ministry of Social Care, and not the other way round, they might come to the conclusion that poverty and misfortune are rare problems here, which is why nowadays so relatively little is spent on social care [Sejm IV, form 300/14: 2].

As early as 1931, when relatively high amounts were spent on social purposes, senator Jerzy Barański claimed that "in general, when it comes to the ministerial budget, we can say it has just one flaw: it is very, very insufficient" [Minutes, March 6, 1931: 54].

Senator Józef Danielewicz expressed a similar view four years later ("the budget of the Ministry of Social Care has great significance, but minimum means"). In 1938, Franciszek Urbański, MP, said that the ministerial budget should be three or four times larger, and in March 1939, Bolesław Fichna said in the Senate that: 


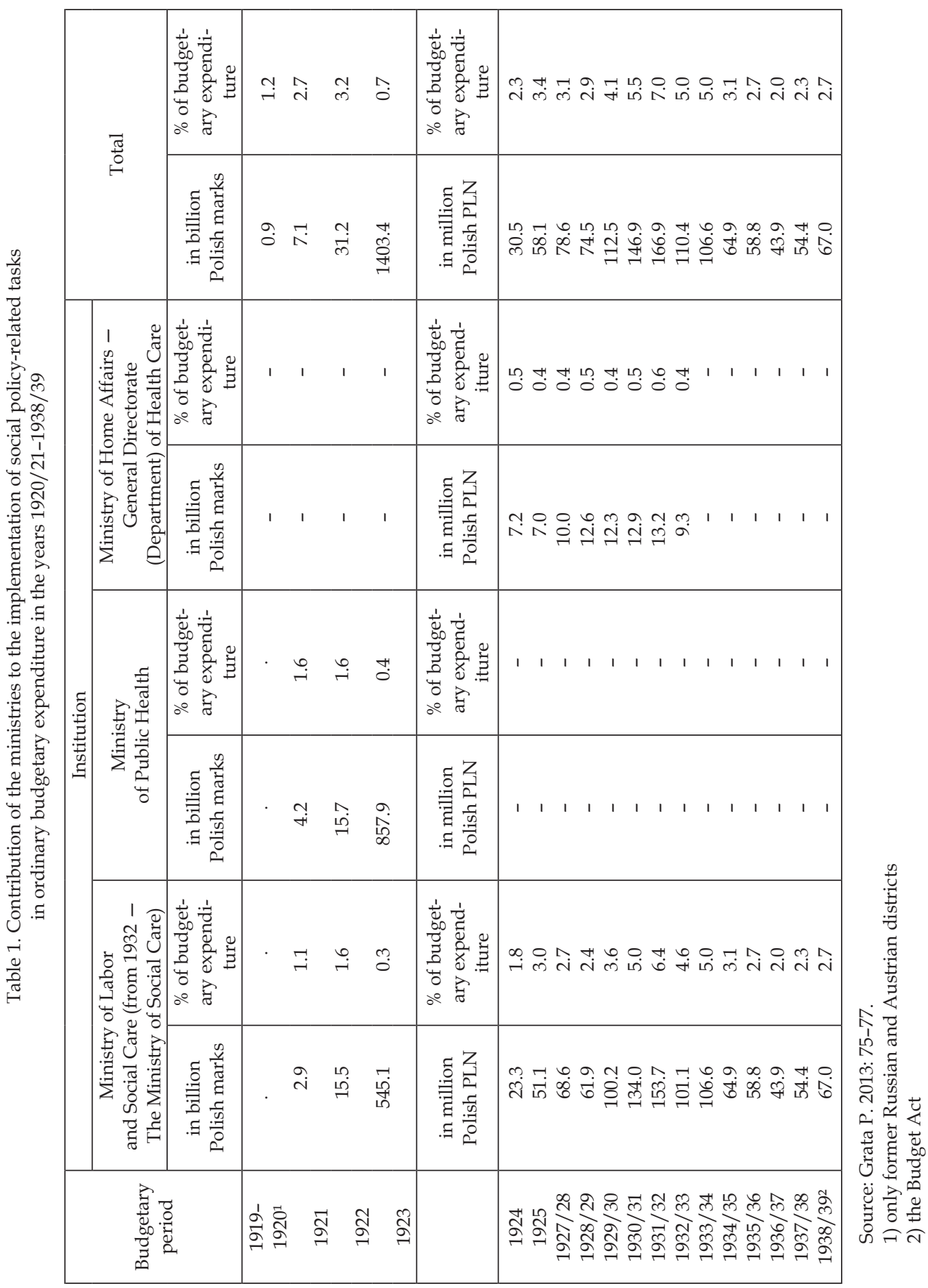


when it comes to the resources, it is clear that they are modest, while the needs are disproportionately large. There is nothing new about this conclusion, nor am I the first one to state this. We have been emphasizing this fact for several years, and when it comes to other ministries, we can see a similar symptom. You simply have to make use of the fabric that has been given to you [Minutes, March 16, 1939: 3].

Similar "tailoring" analogies had already been used in 1934, by Stefan Hubicki, the Minister of Social Care. Despite evident limitations, it is worth remembering that even the structure of using the "fabric" resulted from political decisions, and these always put social issues at the end of the budgetary priority list [Minutes, February 17, 1938: 37; Minutes, February 28, 1934: 42-61; Minutes, March 2, 1935: 48].

This thesis is also confirmed by the comparison of fiscal expenditure on social purposes in Poland and in other countries. In the budgetary year 1928/1929, 62 million PLN was spent on labor and social care (excluding health care). In Czechoslovakia, in 1928, nearly 229 million PLN was spent, and in Austria - 302 million. This meant that these countries spent respectively $9 \%$ and nearly $15 \%$ of their budget for this purpose, while Poland only spent $2.4 \%$. At the same time, in Germany, $7 \%$ of the budget (nearly 1.5 billion PLN) was spent on social policy, and in France, a little over $2 \%$ - which was similar to Poland, but resulted from the fact that the budget itself was simply much larger. The per capita spending index confirms that. In France, in 1928, 7.66 PLN per capita was spent for social purposes, while in Poland, this was only 2.07 PLN (in Germany, the figure was a staggering 22.97 PLN). In the initial period of the depression, expenditure in Poland even grew to over 4 PLN per capita, but from the year 1934/1935 on it dropped below 2 PLN again. Exceeding this level turned out to be impossible until the end of the decade [Sejm V, form 100/14: 17; Senate II, form 18/15: 6-7; own calculations].

Of course, the amounts presented above were not the only resources allocated for social needs. In the state budget alone, there were two other items that absorbed significantly more resources than the budgets of the ministries directly related to social care. These were pensions and disability benefits. The Treasury dedicated a little over $10 \%$ of the budget for these purposes, and in the early 1930s, their share was the highest and amounted to $13 \%$ of the budget. Later on, a reduction of disability benefits meant that $11 \%$ of the budget was spent on pensions and benefits. It is worth noting that in second half of the 1930s, the pensions for state officials, professional army men, and state company employees consumed 160-170 million PLN from the state budget annually - this was more than twice as 
much as the Ministry of Social Care received. Around 100 million annually was spent on benefits for disabled war veterans - also more than what was spent on broadly understood social care in the Ministry of Social Care [Maty... (Short...), 1939: 294, 356; Grata P. 2014a: 403].

From the point of view of contemporary social policy, expenditure on pensions and benefits must be considered its integral component. This would mean that social needs consumed not 3\% of the state budget or less, but around $14-15 \%$. However, considering the reality of the time, this interpretation is not justified. Disability benefits and pensions were permanent, long-term allowances, hard to associate with financing for current activities undertaken within social policy - similarly to the capital in possession of social insurance institutions. Paying out pensions to former state employees from the state budget was a traditional responsibility of the state, and in its origins, was not related to the concept of social policy as understood back then. War disability benefits were the state's way of fulfilling its obligation towards those citizens who had lost the ability to earn money when fighting its wars. None of these were in any way related to the functioning of the Ministry of Labor and Social Care and, later on, the Ministry of Social Care. The clear division in this respect was evidenced by the fact that the Ministry was responsible for providing care for the disabled, but at the same time had nothing to do with distributing disability benefits [Jarosz-Nojszewska A. 2010: 203-214] ${ }^{1}$.

The resources and expenses of the Labor Fund, which was separated from the Ministry of Social Care budget and played an extremely important role in implementing the employment policy, must be treated differently. Practically from the very beginning, the expenses of the Fund were much higher than resources allocated to the Ministry of Social Care. The source of this disproportion is the non-budgetary character of this institution, equipped by the legislator with its own sources of income. Thus, when the Ministry of Social Care had around 50-60 million PLN annually to implement all its tasks, the Labor Fund generated an income of 88.3 million PLN in its first year of operation, and from the year 1935/1936 on, it regularly generated 150-160 PLN annually and spent only slightly less. The non-budgetary character of the Labor Fund and the clear disproportion between the size of resources at its disposal and those assigned to "stand-

${ }^{1}$ Legal basis for pensions for former state officials and professional army men was provided by the Act of December 11, 1923 (later amended several times), and disability benefits were introduced by the Act of March 18, 1921 [Dz. U. 1921: 32/195; 1924: 6/46]. 
ard" social care institutions once again confirmed the thesis that social policy was severely underfunded, even marginalized in the state budget [Maty... 1939: 390; Preliminarz (Budgetary estimation...) 1939: 1084-1098].

It is worth noting here that a large share of expenses related to social care and health care was excluded from the state budget and transferred to local governments in accordance with the existing legislation. From the early 1930s, local authorities spent even ten times more on health care than what was provided for in the state budget. In subsequent years, as a result of the deteriorating financial standing of local governments, this disproportion significantly diminished (in the late 1930s, the difference was five-fold). In the case of social care, the amounts spent by local governments were formally similar to the expenses included in the state budget. However, in reality, the Ministry of Labor and Social Care spent only a fraction of the means listed as "social benefits" on strictly social purposes, which meant that local governments actually spent several times more than the state, just like in the case of health care. What is also important, these amounts were still grossly inadequate, compared to the needs. This was evidenced both by the underdevelopment of public health care (in the second half of the 1930s, only $20-25 \%$ of the population had access to certain forms of medical treatment) and by very low expenditure on social care in comparison with other countries [Grata P. 2013: 93-94; idem 2015: 27-28, 33-34].

\section{STRUCTURE OF BUDGETARY SOCIAL EXPENSES}

In the discussed period, the structure of the state's social expenses confirmed the above thesis that expenditure in this field of public life was insufficient. This was evidenced by both the amounts spent on particular tasks, and by the priorities, which had little to do with actual social needs and resulted from the existing legal situation. This meant that most of the available means had to be spent in a way imposed by the existing legislation, which led to significant reductions in expenses on the current activity directly related to alleviating social problems, occurring on a large scale.

Until the point when all aspects of current social activity of the state were consolidated in the Ministry of Social Care, the structure of expenses must be analyzed separately for the Ministry of Labor and Social Care and for the Ministry of Home Affairs. In the first case, global expenses were 
Table 2. The structure of expenses of the Ministry of Labor and Social Care in the years 1924-1932/1933

\begin{tabular}{|c|c|c|c|c|c|c|c|c|}
\hline \multirow[b]{2}{*}{$\begin{array}{c}\text { Budgetary } \\
\text { period }\end{array}$} & \multicolumn{8}{|c|}{ Expenses (in \%) } \\
\hline & 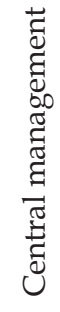 & 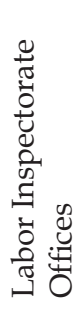 & 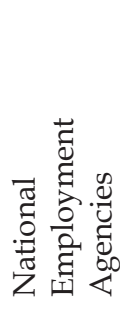 & 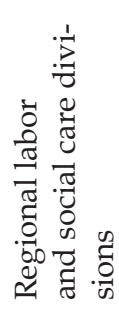 & 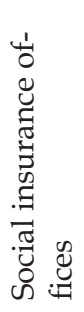 & 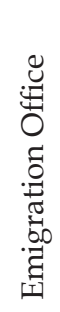 & 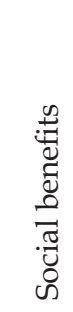 & 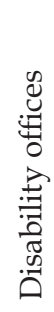 \\
\hline 1924 & 3.2 & 3.5 & 2.6 & 1.9 & 0.7 & 1.6 & 86.5 & - \\
\hline 1925 & 2.1 & 2.3 & 1.3 & 0.7 & 0.4 & 2.4 & 90.8 & - \\
\hline 1926 & 1.4 & 1.5 & 0.9 & 0.4 & 0.3 & 1.1 & 94.4 & - \\
\hline $1927 / 28$ & 1.9 & 2.3 & 1.3 & 0.5 & 0.5 & 2.4 & 91.1 & - \\
\hline $1928 / 29$ & 3.2 & 3.2 & 1.6 & 0.7 & 0.7 & 4.4 & 86.2 & - \\
\hline $1929 / 30$ & 2.9 & 3.5 & 1.6 & 0.8 & 0.7 & 6.2 & 82.6 & 1.7 \\
\hline $1930 / 31$ & 1.3 & 1.6 & 0.8 & 0.6 & 0.3 & 3.3 & 91.3 & 0.8 \\
\hline $1931 / 32$ & 0.8 & 1.2 & 0.6 & 0.5 & 0.3 & 2.3 & 93.8 & 0.5 \\
\hline $1932 / 33$ & 1.2 & 1.7 & 0.8 & 0.6 & 0.4 & 1.8 & 92.8 & 0.7 \\
\hline
\end{tabular}

Source: author's own work based on: Preliminarz..., 1927: 195; Zamknięcia..., 19281934.

very dynamic, and amounted to slightly more than 23 million PLN in the year 1924, and nearly 154 million PLN in the year 1931/1932. Despite this dynamics, a relatively durable structure of these expenses can be observed, dominated by an item termed "social benefits". These consumed from over $82 \%$ in the most prosperous period of the second half of the 1920 s to as much as $94 \%$ in the year 1926 (strong increase in unemployment and expenses related to providing support for the unemployed) and in the early 1930s, when expenses related to support for the unemployed increased rapidly. At this point over 100 million PLN was spent annually on social benefits (and even 144 million PLN in the year 1931/1932).

Among other categories of ministerial expenses, the largest amount, up to several million PLN annually, was spent on the functioning of the Emigration Office. Other purposes related to maintaining central administration, labor inspection offices, employment agencies, regional labor and social care divisions, social insurance offices, and disability offices received less funding and, as a result, their work was often criticized. The most striking example was the situation of the Labor Inspectorate, which, 
due to financial limitations, was constantly struggling with understaffing and unable to fully perform its tasks related to supervising compliance with the labor code [Preliminarz, 1927: 195; Zamknięcia (Summary of national expenditure), 1924-1932; Klott M. 1937: 23-28].

The structure of budgetary expenses for social purposes changed once the management of these issues was consolidated in the Ministry of Social Care. The change resulted from the fact that health care issues were added to the tasks of the Ministry, as well as from a significant decrease of the allocated amounts. The year 1933/1934 (when the Ministry spent significant amounts on tackling unemployment) was the only one when the ministerial budget exceeded 100 million PLN. In subsequent years, it shrunk by more than half, and only exceeded 60 million PLN in the late 1930s. Along with the shrinking of resources at the Ministry's disposal, the share of social benefits in the structure of expenses also diminished - from the year $1936 / 1937$ on, less than $70 \%$ of the ministerial budget was spent on this item (the year 1937/1938 was exceptional in this respect, as only $44 \%$ of the budget was spent on social benefits). In absolute terms, this translated into around 40 million PLN annually (compared to 85 million in the year 1933/1934), and in the years 1936/1937 and 1937/1938 - 20 million PLN. [Preliminarz... 1939: 515; Zamknięcia... 1934-1938].

From the year 1933/1934, health care-related departments started to take an important position in the structure of ministerial expenses. However, when one assesses the level of state engagement in satisfying public needs, the clear dominance of expenses related to providing health care for state officials within the entire health care budget is very symptomatic. This purpose usually consumed around 7-8 million PLN, and in the exceptional year 1937/1938 this amount was even doubled as the budget had to repay a part of the debt incurred during the Depression (the increase of expenses for this purpose was the reason why so little was spent on social benefits that year). ${ }^{2}$

Over $10 \%$ of the Ministry of Social Care budget was regularly spent on medical treatment for state officials (a relatively small group), while annual spending on public health care in the second half of the 1930s was 5 million, i.e. several percentage points fewer. Among other items in the ministerial budget, one can notice an increase in amounts spent on central and regional administration, which was related to its expanding competenc-

\footnotetext{
${ }^{2}$ On December 1, 1937 the debt of Ministry of Social Care associated with this category of spending amounted to 12 million PLN [Sejm IV, form 700/14: 30].
} 
Table 3. The structure of expenses in the Ministry of Social Care in the years 1933/1934-1939/1940

\begin{tabular}{|c|c|c|c|c|c|c|c|c|c|c|c|c|}
\hline \multirow[b]{2}{*}{$\begin{array}{c}\text { Budget- } \\
\text { ary } \\
\text { period }\end{array}$} & \multicolumn{12}{|c|}{ Expenses (in \%) } \\
\hline & 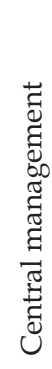 & 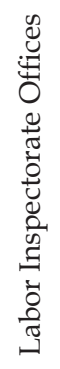 & 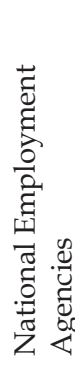 & 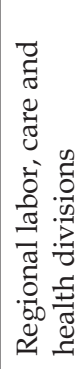 & 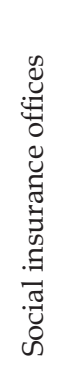 & 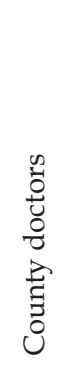 & 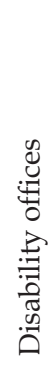 & 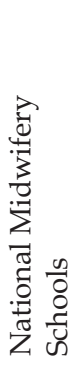 & 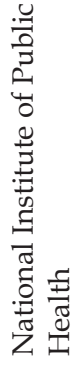 & 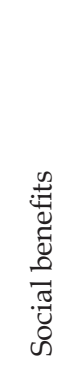 & 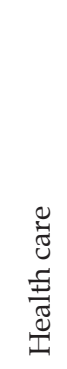 & 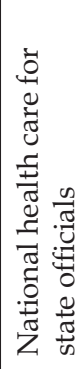 \\
\hline $1933 / 34$ & 1.7 & 1.4 & 0.7 & 0.9 & 0.3 & 1.1 & 0.6 & 0.1 & 1.0 & 80.6 & 4.3 & 7.3 \\
\hline $1934 / 35$ & 3.3 & 2.0 & - & 1.7 & 0. & 1.6 & 0.8 & 0.2 & 1.4 & 71.9 & 5.7 & 10.9 \\
\hline $1935 / 36$ & 3.6 & 2.3 & - & 1.8 & 0.4 & 1.7 & 0.8 & 0.2 & 1.5 & 70.9 & 6.0 & 10.8 \\
\hline $1936 / 37$ & 5.0 & 3.1 & - & 2.5 & 0.6 & 2.3 & 1.1 & 0.3 & 2.1 & 58.9 & 10.3 & 13.8 \\
\hline $1937 / 38$ & 4.5 & 2.9 & - & 3.0 & 0.5 & 2.0 & 1.1 & 0.2 & 2.4 & 44.2 & 9.3 & 29.9 \\
\hline $1938 / 39^{1}$ & 3.9 & 3.0 & - & 2.5 & 0.4 & 1.6 & 0.9 & 0.2 & 2.1 & 65.8 & 7.1 & 12.5 \\
\hline
\end{tabular}

${ }^{1}$ the Budget Act

Source: author's own calculations based on: Preliminarz..., 1939: 515; Zamknięcia..., 1934-1938.

es. The share of these expenses in the budget also increased significantly at the beginning of the second half of 1930s, though this mainly resulted from the fact that the budget was simply smaller in this period (in the late 1930s, the share returned to the level from the middle of the decade).

Three main areas of expenditure can be distinguished within the most important item in the ministerial budget in the discussed period, i.e. social benefits: employment and migration, social insurance, and social care. By far, most resources were spent on employment-related issues: from $1 / 3$ of the amount spent in this department in the mid-1920s, up to $86 \%$ in the beginning of the 1930 s. This share included a statutory $50 \%$ subsidy to unemployment insurance contributions, temporary support for the unemployed not entitled to unemployment benefits, and public works. After the Labor Fund had been created, i.e. from the budgetary year 1934/1935 on, the employment-related expenses clearly dropped, comprising less than twenty percent of this part of the budget in the second half of the 1930s. Notably, they were always much lower than the amounts provided for in fiscal acts. This resulted from the fact that the budget transferred less than $10 \%$ of the due unemployment contribution amounts, while the 
rest was used to pay the outstanding loans granted to the Unemployment Fund (as it was called back then) in the time of the Depression [Sejm V, form 100/14: 32-33; Preliminarz... 1938: 536-537; Sprawozdanie... (The report...) 1934: 19; Sprawozdanie... 1937: 16].

The level of expenditure on social insurance was, due to its character, relatively stable, as these expenses were fixed by the existing legal acts. In the 1920 s, around $20 \%$ of the amounts in the department of social benefits was spent on insurance (from several to dozen or so million PLN annually), and in the next decade, this share increased to nearly $40 \%$ (around 10-12 million annually) as a result of the broadening of the state's responsibilities in this respect. Until the early 1930s, the Treasury transferred most funds to health insurance section to subsidize maternity allowances. Significant amounts were also spent on disability benefits for residents of the former Prussian partition territory. Later, after the budgetary subsidy for maternal allowances was discontinued, most funds were spent on subsidies for disability benefits (around 5 million PLN annually) and several million were spent on covering the liabilities of insurance companies from the former Prussian partition taken over by the state. Around one million was spent on benefits for returnees and Polish miners from Germany who had lost their benefits due to their departure to Belgium and France. As in the case of other items in the budget of the Ministry of Social Care, budgetary expenses related to statutory subsidies for social insurance remained unsatisfactory, which progressively increased the state's debt [Preliminarz... 1926: 246-247; 1928: 203; 1938: 530-533; 1939: 515, 550-553; Zamknięcia... 1934-1938; own calculations].

In the second half of the 1930s, when expenses related to tackling unemployment were transferred out of the Ministry of Social Care budget, care provision became the priority in social benefit spending. This expenditure was quite stable, and amounted to around 10-11 million PLN annually in the 1930s. Its fluctuating contribution in this item of the ministerial budget was inversely proportional to expenditure on employmentrelated purposes, and increased from merely $9 \%$ in the year 1931/1932 to nearly $50 \%$ in the year $1937 / 1938$. Expenses on care provision did increase somewhat right before the Depression - in the year 1929/1930 and 1930/1931 they even amounted to 20 million PLN. However, along with the deteriorating condition of the budget, they drastically decreased, and the only exception to this rule was the year 1935/1936, when the budget for care provision exceeded 13 million PLN, which was related to repair- 
ing the damage caused by the great flood of 1934 [Sejm III, form 800/14: 4; Preliminarz... 1934: 366-367; 1938: 536-537].

Most resources in this part of the social benefits budget was spent on supporting care for children and adolescents. In the late 1920s, as much as 9.4 million PLN was spent on this purpose. Later, however, expenses were permanently limited to merely 5 million annually, and remained at this level until the end of the discussed period. Combined with the diminishing social expenses of local governments, this situation could only mean less potential for action in this respect. The Ministry of Social Care actively supported the institution of foster families in an attempt to minimize the consequences of insufficient financing. This form of aid was considered the most beneficial from the point of view of a child's needs, but also much cheaper than closed institutions, which dominated at that time [Preliminarz... 1939: 552-553; Zamknięcia... 1928-1938; Nakoniecznikow Klukowski B. 1938: 22].

Very little, less than a million PLN annually, was spent in the 1930s on providing assistance to adults unable to work - this once again showed that the state's direct involvement in care provision was limited. According to the estimates for the year 1936/1937, total national expenditure on social care amounted to 102 million PLN, out of which only $10 \%$ was contributed from the budget of the Ministry of Social Care (around 40 million was spent on care provision by local governments; a little less by the socalled Winter Aid, which was formally a social initiative, but was largely organized by the administration; and more than 10 milion PLN was spent by the Labor Fund for temporary aid for the unemployed) [Preliminarz... 1939: 554-555; Sejm IV, form 700/14: 22].

Among other items, the biggest role was played by medical care and care provision for war veterans - several million PLN was spent annually on these purposes. Similar to spending on care provision for children and adolescents, these expenses were very stable. Other important items on the social care expenditure list were more dynamic, including support for returnees, victims of political circumstances, and victims of natural disasters. In the former case, the amount of support depended on migration-related needs, therefore most resources were allocated for this purpose in the mid-1920s, when the Ministry of Labor and Social Care supported repatriates, returnees, Silesia migrants, Polish optants from Germany, and also Ukrainian, Georgian, and Russian allies from the period of the Polish-Bolshevik war seeking asylum. In the case of support for natural disaster vic- 
tims, the amount of loans depended on the occurrence of such disasters. Definitely most was spent on this purpose after the flood of 1927, when, owing to a good condition of the budget, over 9 million PLN was spent in the year 1927/1928 on support for victims and rebuilding destroyed houses [Grata P. 2013: 247-253; Preliminarz... 1939: 554-557; Zamknięcia... 19281938].

The size of expenditure on broadly understood health care confirms that the state's financial engagement in solving social issues was fundamentally limited. As pointed out above, most resources in this area were spent on providing medical care to public officials. Actions aiming at providing public access to health care were left to local governments. The most important budgetary item in the state budget was tackling social and infectious diseases - 2-3 million annually. Maintenance of medical care in the 1920s consumed only 1.5 million. In the next decade, this amount dropped to less than a million, and only exceeded 1 million PLN again as late as the second half of the 1930s (up to nearly 1.5 million in the year 1937/1938). Substantial progress in this respect was the result of larger subsidies for mothers and children and support for medical centers run by local governments. Still, those amounts were small - only several hundred thousand PLN annually [Preliminarz... 1939: 558-565; Zamknięcia... 1928-1938].

\section{CONCLUSIONS}

Concluding this short review of the way social policy financing was shaped in the Second Polish Republic, one might notice that social issues not only played a minor role in the state budget, but also showed no upward tendencies in the long term. Furthermore, expenditure in this area was much lower in Poland than in other European countries. The structure of expenditure also confirmed this rather negative assessment, as the state spent most resources on purposes required by the existing legislation, while the expenditure structure hardly showed any ongoing ambition to solve fundamental social problems. The marginal treatment of health care and social care remains a striking example - it is true that these issues were technically the responsibility of local governments, but were scarcely supported by the state despite constant reminders of deficits in this respect. 
In general, one might reiterate what the experts in the field said back then: the budget of the Ministry of Social Care always lacked resources for everything. Very often even the expenses that the state was obliged to cover were financed at an insufficient level and generated additional debt in the budget, which even then did not increase in size (examples include insufficient subsidies for social insurance or incomplete financing of medical treatment for state officials). The situation was even worse with regard to those items that were affected by political decisions and burdened by the current economic conditions. In this case, even financing the Labor Inspectorate, an institution indispensable from the point of view of implementing traditional social policy-related tasks, despite its importance and relatively low cost, became a problem that remained unsolved throughout the inter-war period. Such budgetary decisions led to insufficient financing in most aspects of the social influence of the state, which remained the norm, as reflected by the constant shortages in social policy task performance.

In the Second Polish Republic, it was possible to create an advanced and quite modern legal and institutional framework for social policy, but the insufficient funding made it impossible to implement effectively. Therefore, the thesis that the period between the two world wars was the initial phase of the Polish welfare state (in terms of budgetary policy) would be difficult to prove. To the contrary, it should be noted that expenditure for social purposes was marginal, and fiscal limitations determined the practical dimension of the state's functioning and presence in the social field. Transformations in this area would only occur after the WWII, when the enormous social needs forced public institutions to become much more engaged in solving large-scale social problems. As a result, right after the WWII, the share of social expenses in the state budget amounted to $9-10 \%$, and in the second half of the 1940 s exceeded $8 \%$ three times more than the decade before, regardless of many shortcomings in the performance of social tasks. Thus, considering the financial dimension, it is in that period that the origins of welfare state in Poland may be found [Zamknięcia... 1948-1951; own calculations; see also Grata P. 2018]. 


\section{BIBLIOGRAPHY}

\section{Printed sources:}

Journal of Laws of the Republic of Poland (Dz. U.) 1921, 1924, 1933, 1934.

Preliminarz Budżetowy Rzeczypospolitej Polskiej na rok 1926 (Budgetary estimations for the year 1926] (1926), Ministry of Treasury, Warsaw.

Preliminarz... [Budgetary...] 1927/28 (1927), Ministry of Treasury, Warsaw.

Preliminarz... [Budgetary...] 1928/29 (1928), Ministry of Treasury, Warsaw.

Preliminarz... [Budgetary...] 1934/35 (1934), Ministry of Treasury, Warsaw.

Preliminarz... [Budgetary...] 1938/39 (1938), Ministry of Treasury, Warsaw.

Preliminarz... [Budgetary...] 1939/40 (1939), Ministry of Treasury, Warsaw.

Sejm, term III, form 800

Sejm, term IV, form 300

Sejm, term IV, form 700

Sejm, term V, form 100

Senate, term II, form 18

Minutes of the $71^{\text {st }}$ session of the Sejm, term IV, February 17, 1938, paragraph 37.

Minutes of the $11^{\text {th }}$ session of the Senate, term III, March 6, 1931, paragraph 54.

Minutes of the $61^{\text {st }}$ session of the Senate, term III, February 28, 1934, paragraph 42, 61 .

Minutes of the $74^{\text {th }}$ session of the Senate, term III, March 2, 1935, paragraph 48.

Minutes of the $12^{\text {th }}$ session of the Senate, term V, March 16, 1939, paragraph 3.

Sprawozdanie $z$ działalności Funduszu Bezrobocia 1933 [The report on the activity of the Unemployment Fund 1933] (1934), Unemployment Fund, Warsaw

Sprawozdanie z dziatalności Funduszu Pracy za okres od 1 kwietnia 1936 r. do 31 marca 1937 r.

[The report on the activity of the Labor Fund from April 1, 1936 to March 31, 1937] (1937), Labor Fund, Warszawa.

Zamknięcia rachunków państwowych za lata 1924-1936/37 [Summary of national expenditure for the years 1924-1935/37] (1928-1938), Ministry of Treasure, Warsaw.

Zamknięcia rachunków państwowych za lata 1944/1945-1949 [Summary of national expenditure for the years 1944/1945-1949]

\section{Statistical sources:}

Maty Rocznik Statystyczny 1939 [Short statistical yearbook 1939] (1939), Main Statistical Office, Warsaw.

\section{Literature:}

Bornstein-Łychowska M. (1931), Walka Rządu Polskiego z bezrobociem w okresie ostatniego kryzysu [Polish government's combat against unemployment during the last crisis], "Praca i Opieka Społeczna" [Labor and Social Care] issue 3, p. 358-366

Fundusz Pracy w latach 1933 i 1934 [The Labor Fund in the years 1933 and 1934] (1934), The Labor Fund publication, Warsaw.

Grata P. (2013), Polityka społeczna Drugiej Rzeczypospolitej. Uwarunkowania - instytucje dziatania [Social Policy in the Second Polish Republic. Conditions - institutions - actions], Wydawnictwo Uniwersytetu Rzeszowskiego.

Grata P. (2014a), Problemy skarbowości II Rzeczypospolitej [Fiscal problems in the Second Polish Republic] [in] Między stabilizacją a ekspansja. System finansowy w stużbie modernizacji ( $z$ warsztatów badawczych historyków gospodarczych) [Between stability and expansion. Financial system at the service of modernization (from research workshops of 
economic historians], ed. Łazor J., Morawski W., Wydawnictwo Gajt, Wrocław, p. 387411.

Grata P. (2014b), The system of social care in the Second Polish Republic, "Charity, Philantropy and Social Work" no. 1, p. 69-79.

Grata P. (2015), Social privileges in the Second Polish Republic, "Studia Historiae Oeconomicae" vol. 33, Poznań, p. 19-35.

Grata P. (2016), Na drodze do publicznej stużby zdrowia. Meandry polityki zdrowotnej Drugiej Rzeczypospolitej [Towards public health care. Problems of health care policy in the Second Polish Republic], "Polityka i Społeczeństwo" [Politics and Society] issue 3 (14), p. 129-143.

Grata P. (2018), Czas przełomu. Polska polityka społeczna w latach 1944-1950 [Time of breakthrough. Social policy in Poland in the years 1944-1950], Wydawnictwo Uniwersytetu Rzeszowskiego, Rzeszów (in preparation).

Jarosz-Nojszewska A. (2010), Świadczenia rentowe dla inwalidów wojennych w II RP w latach 1918-1926 [Disability benefits for war veterans in the Second Polish Republic in the years 1918-1926] [in] Gospodarka i społeczeństwo a wojskowość na ziemiach polskich [Economy and society vs. the military system in Poland], ed. Głowiński T., Popiński K., Wydawnictwo Gajt, Wrocław, p. 203-214.

Jarosz-Nojszewska A. (2013), Ubezpieczenia robotnicze w Polsce w latach 1918-1939 [Labor insurance in Poland in the years 1918-1939] [in] Od kwestii robotniczej do nowoczesnej kwestii socjalnej. Studia z polskiej polityki społecznej XX i XXI wieku [From the labor problem to the modern social problem. Studies on the Polish social policy of the $20^{\text {th }}$ and $21^{\text {st }}$ century], ed. Grata P., Wydawnictwo Uniwersytetu Rzeszowskiego, Rzeszów, p. 2640.

Klott M. (1937), Inspekcja Pracy w Polsce, [The Labor Inspectorate in Poland], Ministry of Social Care publication, Warsaw.

Księżopolski M. (1999), Polityka społeczna. Wybrane problemy porównań międzynarodowych [Social policy. Selected problems for international comparison], “Śląsk" Wydawnictwo Naukowe, Katowice.

Muszalski W. (2004), Ubezpieczenie społeczne. Podręcznik akademicki [Social insurance. Academic textbook], Wydawnictwo Naukowe PWN, Warszawa.

Nadolska A. (2003), Polityka budżetowa [Budgetary policy] [in:] Polityka gospodarcza [Economic policy], ed., Ćwikliński H., Wydawnictwo Uniwersytetu Gdańskiego, Gdańsk, p. 106-128.

Nakoniecznikow Klukowski B. (1938), Przeglad najbardziej aktualnych zagadnień z zakresu polityki opiekuńczej [The review of the latest problems in social care], "Praca i Opieka Społeczna" [Labor and Social Care], issue 1. p. 18-26.

Polityka społeczna państwa polskiego 1918-1935 (1935) [Social policy in Poland 1918-1935], Ministry of Social Care, Warsaw.

Paweł Grata (born 1971), dr hab., professor at the University of Rzeszów. His academic interests focus on Polish social policy in the $20^{\text {th }}$ century, economic policy of the Second Polish Republic and economic and social transformation in south-eastern Poland in the second half of the $20^{\text {th }}$ century and early $21^{\text {st }}$ century. He is the author of over one hundred academic publications, including four original monographs: "Polityka społeczna Drugiej Rzeczypospolitej. Uwarunkowania - instytucje - działania" [Social policy in the Second Polish Republic. Conditions - institutions - actions], "Monopole skarbowe w polityce podatkowej Drugiej Rzeczypospolitej" [Fiscal monopolies in the fiscal policy in the Second 
Polish Republic], „Miejsce monopoli skarbowych w reformie stabilizacyjnej Władysława Grabskiego (1923-1925)" [The role of fiscal monopolies in the stabilization reform of Władysław Grabski], „Przemysł gorzelniczy w II Rzeczypospolitej” [Spirit industry in the Second Polish Republic]. He was also an editor for 11 collective monographs, including five volumes of the "Studies on Polish Social Policy of the $20^{\text {th }}$ and $21^{\text {st }}$ centuries" and participated in numerous scientific conferences, both national and international. 